\title{
Retinal Recipient Nuclei in the Painted Turtle, Chrysemys picta: An Autoradiographic and HRP Study
}

\author{
ANDREW H. BASS AND R. GLENN NORTHCUTT \\ Division of Biological Sciences, University of Michigan, Ann Arbor, \\ Michigan 48109
}

\begin{abstract}
Retinofugal pathways in the painted turtle were examined with autoradiographic and HRP methods. The majority of the retinal fibers decussate at the optic chiasm and course caudally to terminate in 12 regions of the diencephalon and mesencephalon. The pars dorsalis of the lateral geniculate nucleus is the densest target in the thalamus. Two nuclei dorsal to pars dorsalis-the dorsal optic and dorsal central nuclei-receive optic input. Three nuclei ventral to pars dorsalis are retinal targets - the ventral geniculate nucleus, nucleus ventrolateralis pars dorsalis, and nucleus ventrolateralis pars ventralis. Contralateral fibers course through the pretectum where they terminate in nucleus geniculatis pretectalis, nucleus lentiformis mesencephali, nucleus posterodorsalis, and the external pretectal nucleus. Retinal fibers also terminate within the superficial zone of the optic tectum. HRP material demonstrates three optic fiber layers-laminae 9, 12, and 14. Optic fibers leave the main optic tract as a distinct accessory tegmental optic pathway and terminate in the basal optic nucleus. Ipsilateral retinal terminals occur in a pars dorsalis and a pars ventralis of the lateral geniculate nucleus, the dorsal optic nucleus, nucleus posterodorsalis, the basal optic nucleus, and in laminae 9 and 12 of the optic tectum. Rostrally, the ipsilateral tectal fibers occupy two zones along the medial and lateral tectal roof; these zones converge caudally and are continuous along the caudal wall of the tectum.
\end{abstract}

\section{INTRODUCTION}

Previous retinofugal studies using silver degeneration methods have resulted in conflicting reports regarding central visual pathways in turtles. Five to ten primary retinal targets have been reported (Kosareva, '67; Knapp and Kang, '68a, b; Hall and Ebner, '70a), and the number of reported thalamic targets alone varies between two (Hall and Ebner,'70a) and five (Knapp and Kang, '68b). In addition, there is at least one report of ipsilateral retinal projections (Kosareva, '67). The nomenclature used in these studies also varies, thus confusing comparisons among turtles and between turtles and other vertebrates.

To facilitate future phyletic and functional comparisons, we examined the retinal projections in the painted turtle, Chrysemys picta, with the relatively recent autoradiographic and horseradish peroxidase (HRP) methods. Our results provide: (1) the first detailed autoradiographic analysis of retinofugal pathways in turtles, identifying twelve primary retinal targets; (2) new evidence for the presence of ipsilateral retinal projections in turtles; and
(3) HRP data on the trajectory of retinal axons terminating in the superficial layers of the optic tectum. A preliminary report of these results was published earlier (Bass, '76).

\section{MATERIALS AND METHODS}

Ten painted turtles (average carapace length of $15 \mathrm{~cm}$ ) received unilateral intraocular injections of 30-100 uCi of ${ }^{3} \mathrm{H}$-proline (New England Nuclear, NET-323) under MS222 anesthesia $(600 \mathrm{mg} / \mathrm{kg})$. Injections were $5-10$ seconds in duration and were made with a $5 \mu$ l Hamilton syringe through an incision in the dorsal temporal corner of the eyelid.into the vitreous humor. Animals were maintained postoperatively at $18-20^{\circ} \mathrm{C}$ for periods ranging from 12.5 hours to 15 days. Following reanesthetization with MS222, animals were perfused transcardially with $0.7 \%$ saline followed by AFA (90 cc of $80 \%$ ethanol, $5 \mathrm{cc}$ glacial acetic acid, 5 cc formalin). The brains were removed from the skull, placed in fixative for 1 week,

Dr. Andrew H. Bass's present address is Department of Ecology and Behavioral Biology, University of Minnesota, 108 Zoology Building, 318 Church Street, S.E., Minneapolis, Minnesota 55455. 
and subsequently embedded in paraffin and sectioned serially on a rotary microtome at $15 \mu$. The mounted sections were deparaffinized, coated with Kodak NTB2 or NTB3 nuclear track emulsion, and exposed at $7^{\circ} \mathrm{C}$ for 20-28 days. After development in Kodak D-19, sections were counterstained with cresyl violet, and representative sections photographed on Kodalith Orthofilm, type 3, with a Leitz largeformat camera. Tracings of the high-contrast photographs were used to chart the distribution of silver grains. As in similar studies (Butler and Northcutt, '78; Northcutt, '77), terminal fields were considered to be those regions exhibiting increased silver grain density relative to the silver grain density in the adjacent optic tract.

Cytoarchitectonic analysis was based on nonexperimental material embedded in paraffin, cut in the transverse plane at $15 \mu$, and stained by cresyl violet or Bodian methods.

In addition, intraocular injections of HRP (3-5 $\mu$ l of Sigma Type VI; $25 \%$ solution dissolved in distilled water) were made in four juvenile turtles. Orthograde transport of the HRP yielded a clear profile of retinal axons and terminals and provided a check on the autoradiography. The HRP results were particularly useful in identifying the course of optic fibers within the superficial zone of the optic tectum.

All HRP injections were made with a Hamilton syringe in a manner similar to that described for proline injections. After survival times of 2-3 days, animals were reanesthetized with MS222 and perfused transcardially with cold phosphate buffer ( $\mathrm{pH} 7.4$ ) followed by $2 \%$ gluteraldehyde in cold buffer. Following perfusion, each brain was removed from the skull and washed in cold fixative with $30 \%$ sucrose for 12 hours. Frozen brains were sectioned at $40 \mu$ and stored in cold buffer. The sections were stained according to the buffered dianisidine (brown) or unbuffered dianisidine (green) reaction described by Colman et al. ('76).

\section{RESULTS}

\section{Normal anatomy}

Kosareva ('67) was the first to use reduced silver stains to trace degenerating axons and terminals following enucleations in a turtle (Emys orbicularis). She used the nomenclature of Papez ('35) to identify thalamic and pretectal nuclei, and that of Huber and Crosby ('33, '43) to describe the optic tectum. Knapp and Kang ('68a, b) essentially used the terminology of Huber and Crosby ('26, '33) in their degenera- tion studies of retinal pathways in Chelydra serpentina and Podocnemis unifilis. Finally, Hall and Ebner ('70a) used Papez's ('35) nomenclature to identify retinal targets in Pseudemys scripta. Although Papez's study is one of the earliest analyses of the reptilian diencephalon, more recent studies of the reptilian diencephalon (Senn, '68; Butler and Northcutt, '73; Repérant, '73; Cruce, '74; Northcutt and Butler, $74 \mathrm{a}, \mathrm{b})$ have employed a nomenclature that is essentially Kuhlenbeck's ('31). Our study utilizes the nomenclature of Butler and Northcutt ('73, as adapted from Kuhlenbeck, ' 31 and Senn, '68) to facilitate comparisons among reptiles, as this terminology is used in retinofugal studies of lizards (Butler and Northcutt, ' 71 , '78; Northcutt and Butler, '74a; Cruce and Cruce, '78; Repérant et al., '78) snakes (Northcutt and Butler, '74b; Repérant and Rio, '76), a tuatara (Northcutt et al., '74) and crocodilians (Braford, '73). Table 1 lists the correspondence between terms used in this and previous studies of the diencephalon and mesencephalon in turtles.

\section{Experimental results}

Optic nerve fibers course caudally along the ventral surface of the diencephalon, and the majority of the fibers decussate at the optic chiasm and continue caudally along the ventrolateral surface of the hypothalamus. A number of fibers do not cross at the chiasm, however, but continue along the medial aspect of the ipsilateral optic tract. The contralateral and ipsilateral projections will be discussed separately.

Contralateral projections. Labeled retinal efferents course through the lateral hypothalamus en route to the thalamus, pretectum, and optic tectum. Within the hypothalamus, the decussating optic fibers pass ventral to the cell bodies of the preoptic nucleus, but no region exhibits a silver grain density greater than the optic tract. Thus it is difficult to recognize a distinct terminal field. A retinopreoptic target may exist but cannot be firmly established without electron microscopy.

The thalamus of turtles can be divided into a lateral group of retinal-recipient nuclei (Fig. 1). and a medial group of nonretinal-recipient nuclei. As the optic tract courses over the lateral surface of the thalamus, six retinal targets lie medial to the optic tract in the following rostral to caudal sequence: pars dorsalis of the lateral geniculate nucleus; pars ventralis of the lateral geniculate nucleus; pars ventralis of nucleus 
TABLE 1. Nomenclature of Retinal Nuclei

\begin{tabular}{|c|c|c|c|c|}
\hline $\begin{array}{l}\text { Present Usage } \\
\text { in Chrysemys }\end{array}$ & $\begin{array}{c}\text { Papez '35; Chelone } \\
\text { Kosareva ' } 67 ; \text { Emys }\end{array}$ & $\begin{array}{c}\text { Knapp and Kang '68a } \\
\text { Chelydra }\end{array}$ & $\begin{array}{c}\text { Knapp and Kang '68b } \\
\text { Podocnemis }\end{array}$ & $\begin{array}{l}\text { Hall and Ebner '70a } \\
\text { Pseudemys }\end{array}$ \\
\hline $\begin{array}{l}\text { nucleus } \\
\text { ventrolateralis } \\
\text { pars ventralis }\end{array}$ & $\begin{array}{l}\text { nucleus } \\
\text { geniculatis } \\
\text { medialis }\end{array}$ & $\begin{array}{l}\text { lower portion of } \\
\text { pars ventralis of } \\
\text { the lateral } \\
\text { geniculate nucleus }\end{array}$ & $\begin{array}{l}\text { part a of the pars } \\
\text { ventralis of the } \\
\text { lateral geniculate } \\
\text { nucleus }\end{array}$ & \\
\hline $\begin{array}{l}\text { nucleus } \\
\text { ventrolateralis } \\
\text { pars dorsalis }\end{array}$ & & & $\begin{array}{l}\text { subthalamic } \\
\text { nucleus }\end{array}$ & \\
\hline $\begin{array}{l}\text { pars ventralis } \\
\text { of the lateral } \\
\text { geniculate } \\
\text { nucleus }\end{array}$ & $\begin{array}{l}\text { pars ventralis } \\
\text { of the lateral } \\
\text { geniculate } \\
\text { nucleus }\end{array}$ & $\begin{array}{l}\text { upper portion of } \\
\text { pars ventralis } \\
\text { of the lateral } \\
\text { geniculate nucleus }\end{array}$ & $\begin{array}{l}\text { part } b \text { of the pars } \\
\text { ventralis of the } \\
\text { lateral geniculate } \\
\text { nucleus }\end{array}$ & $\begin{array}{l}\text { pars ventralis of } \\
\text { the lateral } \\
\text { geniculate } \\
\text { nucleus }\end{array}$ \\
\hline $\begin{array}{l}\text { pars dorsalis } \\
\text { of the lateral } \\
\text { geniculate } \\
\text { nucleus }\end{array}$ & $\begin{array}{l}\text { nucleus ovalis and } \\
\text { pars dorsalis of } \\
\text { the lateral } \\
\text { geniculate nucleus }\end{array}$ & $\begin{array}{l}\text { nucleus ovalis and } \\
\text { pars dorsalis of } \\
\text { lateral geniculate } \\
\text { nucleus }\end{array}$ & $\begin{array}{l}\text { part c of the pars } \\
\text { ventralis of the } \\
\text { lateral geniculate } \\
\text { nucleus }\end{array}$ & $\begin{array}{l}\text { pars ventralis } \\
\text { of the lateral } \\
\text { geniculate } \\
\text { nucleus }\end{array}$ \\
\hline $\begin{array}{l}\text { dorsal optic } \\
\text { nucleus }\end{array}$ & $\begin{array}{l}\text { caudal nucleus } \\
\text { centralis lateralis } \\
\text { and pars dorsalis } \\
\text { of the lateral } \\
\text { geniculate nucleus }\end{array}$ & & $\begin{array}{l}\text { pars dorsalis of } \\
\text { the lateral } \\
\text { geniculate nucleus }\end{array}$ & $\begin{array}{l}\text { pars dorsalis of } \\
\text { the lateral } \\
\text { geniculate } \\
\text { nucleus }\end{array}$ \\
\hline $\begin{array}{l}\text { dorsal central } \\
\text { nucleus }\end{array}$ & & & & $\begin{array}{l}\text { area } \\
\text { pretectalis }\end{array}$ \\
\hline $\begin{array}{l}\text { nucleus } \\
\text { geniculatis } \\
\text { pretectalis }\end{array}$ & $\begin{array}{l}\text { dorsal } \\
\text { pretectal nucleus }\end{array}$ & $\begin{array}{l}\text { nucleus } \\
\text { geniculatis } \\
\text { pretectalis }\end{array}$ & $\begin{array}{l}\text { nucleus } \\
\text { geniculatis } \\
\text { pretectalis }\end{array}$ & \\
\hline $\begin{array}{l}\text { nucleus } \\
\text { lentiformis } \\
\text { mesencephali }\end{array}$ & $\begin{array}{l}\text { nucleus } \\
\text { lentiformis } \\
\text { mesencephali }\end{array}$ & $\begin{array}{l}\text { nucleus } \\
\text { lentiformis } \\
\text { mesencephali }\end{array}$ & $\begin{array}{l}\text { part of nucleus } \\
\text { geniculatis } \\
\text { pretectalis }\end{array}$ & $\begin{array}{l}\text { nucleus } \\
\text { lentiformis } \\
\text { mesencephali }\end{array}$ \\
\hline \multicolumn{5}{|l|}{$\begin{array}{l}\text { external } \\
\text { pretectal } \\
\text { nucleus }\end{array}$} \\
\hline $\begin{array}{l}\text { nucleus } \\
\text { posterodorsalis }\end{array}$ & area pretectalis & & $\begin{array}{l}\text { nucleus } \\
\text { posterodorsalis }\end{array}$ & $\begin{array}{l}\text { area } \\
\text { pretectalis }\end{array}$ \\
\hline $\begin{array}{l}\text { basal optic } \\
\text { nucleus }\end{array}$ & $\begin{array}{l}\text { nucleus } \\
\text { opticus } \\
\text { tegmenti }\end{array}$ & $\begin{array}{l}\text { nucleus } \\
\text { opticus } \\
\text { tegmenti }\end{array}$ & $\begin{array}{l}\text { nucleus } \\
\text { opticus } \\
\text { tegmenti }\end{array}$ & \\
\hline $\begin{array}{l}\text { superficial } \\
\text { zone of the } \\
\text { optic tectum }\end{array}$ & optic tectum & $\begin{array}{l}\text { stratum zonale, } \\
\text { stratum opticum, } \\
\text { stratum griseum et } \\
\text { fibrosum } \\
\text { superficiale }\end{array}$ & $\begin{array}{l}\text { stratum zonale, } \\
\text { stratum opticum, } \\
\text { stratum griseum et } \\
\text { fibrosum } \\
\text { superficiale }\end{array}$ & optic tectum \\
\hline
\end{tabular}

Correspondence between terminology of this study and that of earlier retinofugal studies. The nomenclature of Papez's ('35) normal analysis is included with Kosareva ('67) since their terms are equivalent. All cell groups listed, except nucleus centralis lateralis (Kosareva, '67), have been identified as retinal targets. Kosareva ('67) does not recognize area pretectalis as a retinal target, although she identifies the nucleus of the posterior commissure (after Papez, '35) as a pretectal target and the suprapeduncular nucleus (after Papez, '35) as a medial thalamic target.

ventrolateralis; pars dorsalis of nucleus ventrolateralis; dorsal optic nucleus; and dorsal central nucleus.

At rostral thalamic levels, the pars dorsalis of the lateral geniculate nucleus (PD, Figs. 1; 2 $\mathrm{A}, \mathrm{B} ; 3 \mathrm{~A} ; 6 \mathrm{~A}, \mathrm{~B}$ ) is composed of a lateral circular neuropil and a medial crescent shaped plate of compact, darkly staining, round or ovoid neurons. The neuropil is particularly distinct in retinal autoradiographs as it contains the highest silver grain density of all thalamic ret- inal targets (Fig. 6B). As nucleus dorsolateralis (DL, Fig. 3A) expands laterally, the cells of the pars dorsalis of the lateral geniculate nucleus become more diffuse, but are distinct from cells of nucleus dorsolateralis in their aggregations, fiber tracts, and retinal terminal fields. A distinct nucleus ovalis, as recognized in some turtles (Kosareva, '67; Knapp and Kang, '68a) and lizards (Butler and Northcutt, '73), is not apparent in Chrysemys.

Just ventral to the pars dorsalis of the lateral 


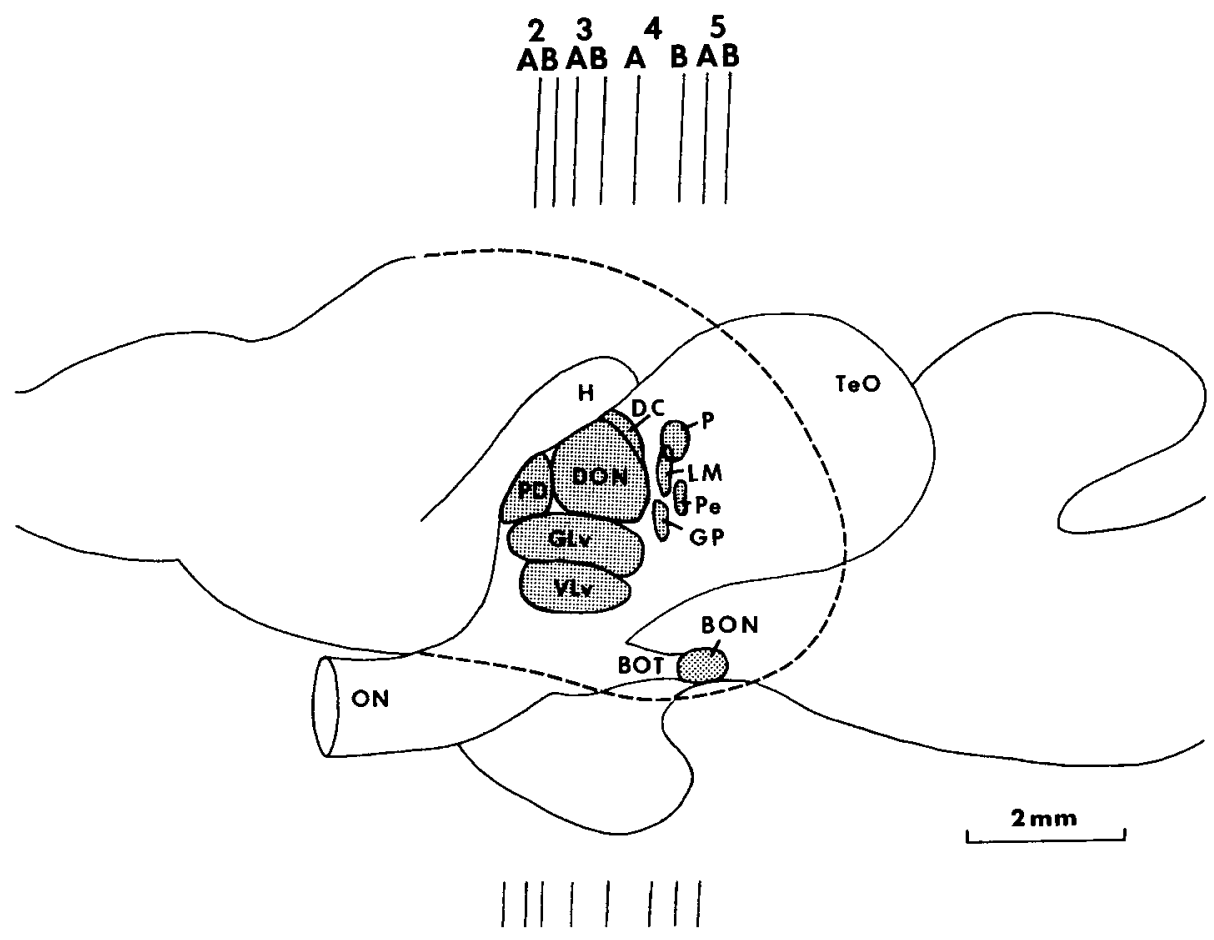

Fig. 1. A lateral view of the brain of Chrysemys picta illustrating position and extent of the major retinal targets along the lateral wall of the diencephalon and the mesencephalon. Numbers 2-5, cross sections depicted in Figures 2-5.

\section{Abbreviations}

AT, area triangularis

BON, basal optic nucleus

BOT, basal optic tract

C, central zone of the optic tectum

DC, dorsal central nucleus

$\mathrm{DL}$, nucleus dorsolateralis

$\mathrm{DM}$, nucleus dorsomedialis

DON, dorsal optic nucleus

$\mathrm{dp}$, dorsal peduncle of the lateral forebrain bundle

$\mathrm{E}$, entopeduncular nucleus

GLV, pars ventralis of the lateral geniculate nucleus

$\mathrm{GP}$, nucleus geniculatis pretectalis

$\mathrm{H}$, habenula

LFB, lateral forebrain bundle

LM, nucleus lentiformis mesencephali

MFB, medial forebrain bundle

N III, oculomotor nucleus
ON, optic nerve

OT, optic tract

$\mathrm{P}$, nucleus posterodorsalis

PC, posterior commissure

$\mathrm{PD}$, pars dorsalis of the lateral geniculate nucleus

$\mathrm{Pd}$, dorsal pretectal nucleus

$\mathrm{Pe}$, external pretectal nucleus

PG, periventricular gray zone of the optic tectum

pp, pars plicata of the nucleus lentiformis thalami

$R$, nucleus rotundus

$\mathrm{RE}$, nucleus reuniens

$\mathrm{S}$, superficial zone of the optic tectum

$\mathrm{s}$, stria medullaris

$\mathrm{TeO}$, optic tectum

Vld, pars dorsalis of nucleus ventrolateral is

VLv, pars ventralis of nucleus ventrolateralis

$\mathrm{vp}$, ventral peduncle of the lateral forebrain bundle 

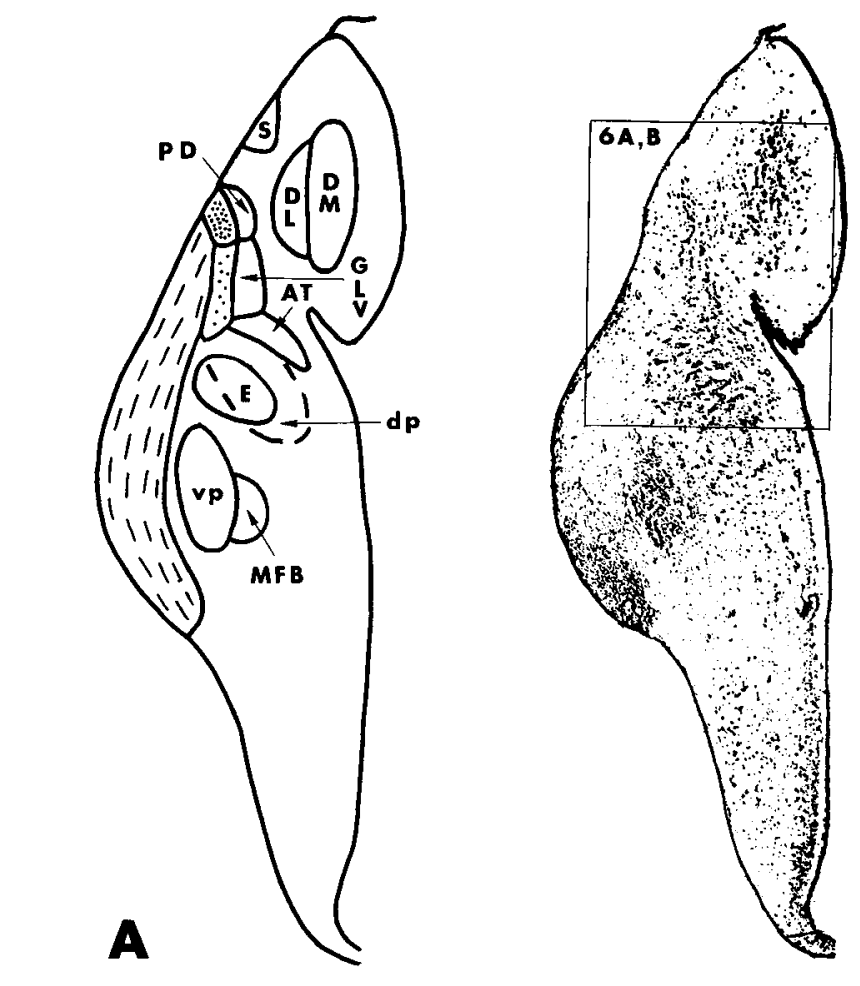

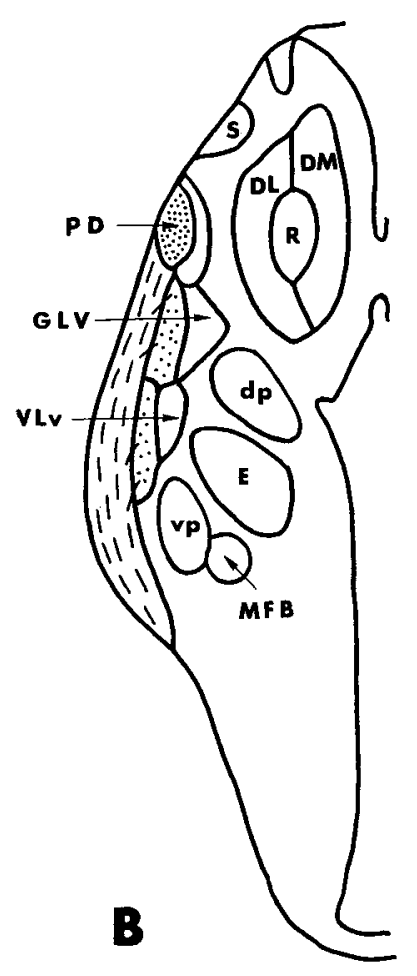

Fig. 2. Transverse sections through the rostral diencephalon of Chrysemys picta. In this figure and Figures 3-5, a Nissl photomicrograph appears on the right and chartings of the contralateral retinal projections appear on the left. Fibers are indicated by dashes and terminal fields by stippling. The autoradiographic data represented here and in Figures 3-8 are based on a case that received an intraocular injection

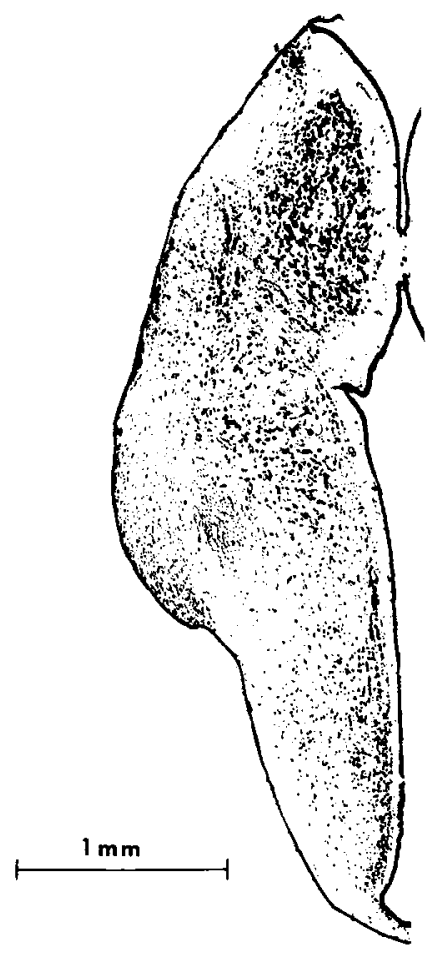

of $60 \mu \mathrm{Ci}$ of ${ }^{3} \mathrm{H}$-proline and survived 48 hours. Bar scale equals $1 \mathrm{~mm}$ for Figures 2-5. A) Transverse section through the rostral pole of the pars dorsalis of the lateral geniculate nucleus (PD). B) Transverse section through the rostral pole of the pars ventralis of the lateral geniculate nucleus (GLV) and the pars ventralis of nucleus ventrolateralis (VLv). 

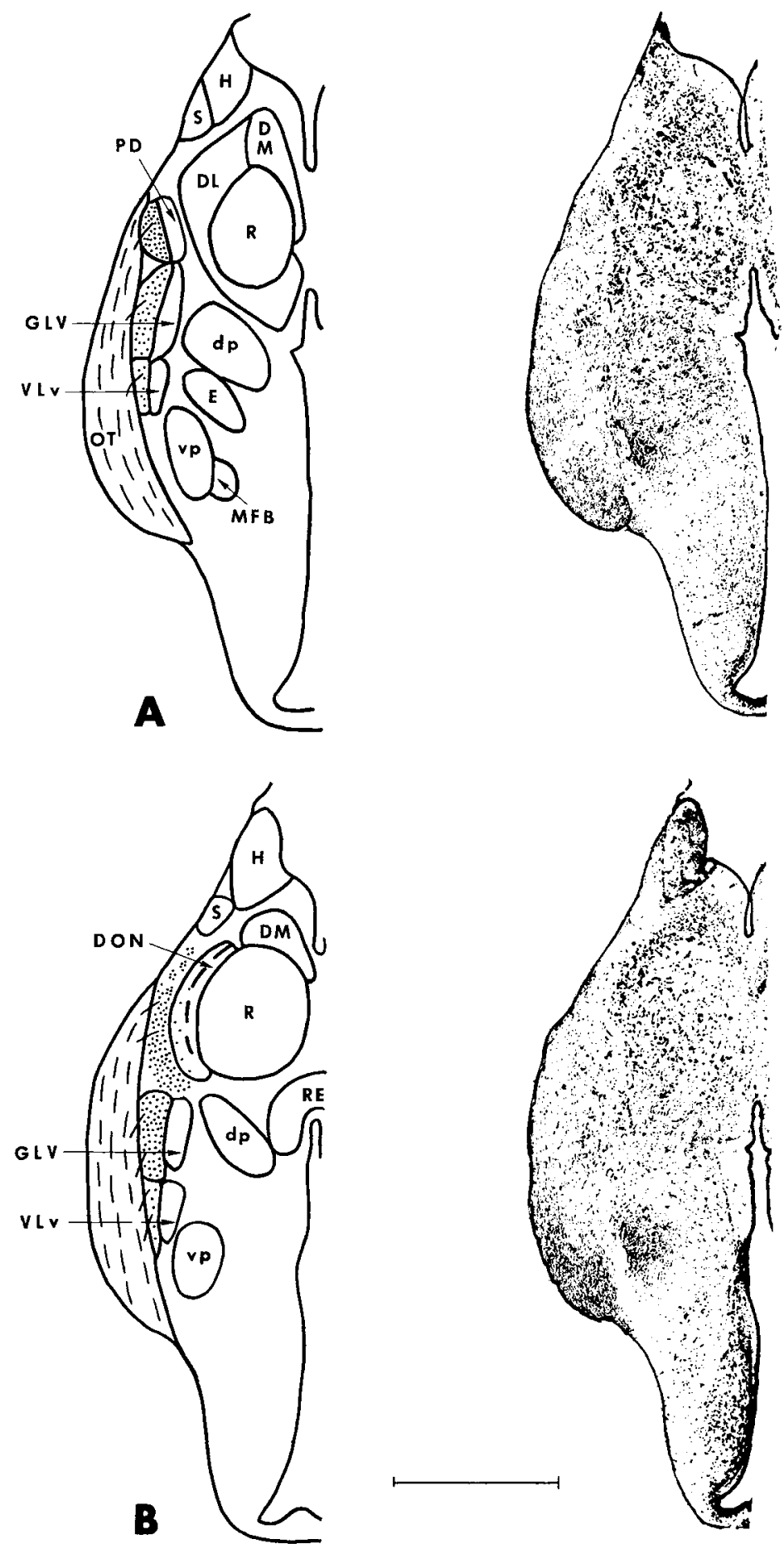

Fig. 3. A: Transverse section through the caudal pole of the pars dorsalis of the lateral geniculate nucleus. B: Transverse section through the middle of the dorsal optic nucleus (DON). 
geniculate nucleus, the pars ventralis of the lateral geniculate nucleus appears (GLV, Figs. $1 ; 2 \mathrm{~A}, \mathrm{~B}$ ). The cell plate is a diffuse group of neurons similar in morphology to those of the pars dorsalis but more lightly staining. In retinal autoradiographs, silver grains over the lateral neuropil of the pars ventralis are markedly less dense than over the neuropil of the pars dorsalis, thus distinguishing the former as a second retinal target. Cells of the pars ventral is form a more distinct cell plate as nucleus dorsolateralis expands laterally (Fig. 3A). Caudally, as the pars dorsalis drops out, the pars ventralis again becomes more diffuse (Fig. 3B) and is dispersed amid a dense neuropil (Fig. 4A).

Ventromedial to the pars ventralis of the lateral geniculate nucleus is a nonretinal-recipient nucleus-area triangularis (AT, Fig. 2A). This compact group of ovoid-shaped, darkly staining neurons continues anterior to the pars dorsalis of the lateral geniculate nucleus as the most rostral cell group in the thalamus. Area triangularis is replaced caudally by another nonretinal-recipient nucleus-nucleus ventromedialis (not figured)and by two retinal-recipient nuclei-the pars ventralis and the pars dorsalis of nucleus ventrolateralis.

The pars ventralis of nucleus ventrolateralis (VLv, Figs. 1; 2B; 3A, B; 4A) lies ventral to the pars ventralis of the lateral geniculate nucleus and consists of a diffuse plate of lightly staining, ovoid-shaped neurons lying medial to a retinal-recipient neuropil. Rostrally, the grain density over this neuropil is comparable to that over the neuropil of the pars ventralis of the lateral geniculate nucleus. Caudally, the grain density associated with both the pars ventralis of nucleus ventrolateralis and the pars ventralis of the lateral geniculate nucleus increases as the pars dorsalis of the lateral geniculate nucleus reaches the lateral border of nucleus dorsolateralis (Fig. 3A).

Retinal input to the pars dorsalis of nucleus ventrolateralis is distinct at caudal thalamic levels (VLd, Fig. 4A) and small grain clumps are scattered amid this ill-defined group of lightly staining, ovoid-shaped neurons.

As retinal efferents continue dorsocaudally along the lateral thalamic wall, some labeled fibers course ventral to a fifth retinal targetthe dorsal optic nucleus (DON, Figs. 1; 3B; 4A; $6 \mathrm{C}, \mathrm{D})$. The dorsal optic nucleus appears as a lateral extension of nucleus dorsolateralis. Rostrally, its medial division of moderately staining neurons appears continuous with nucleus dorsolateralis (Fig. 3B); its lateral divi- sion of deeply staining neurons (Fig. 3B) expands caudally (Fig. 4A), lying medial to an expansive neuropil that receives dense retinal input (Fig. 6D). Autoradiographs reveal clumped silver grains with some grains adjacent to the cell bodies.

Finally, a sixth retinal target-the dorsal central nucleus (DC, Figs. 1, 4A)-appears dorsomedial to the dorsal optic nucleus. This elliptical-shaped group of small, round, lightly staining cells receives a much sparser retinal input than the more ventral dorsal optic nucleus. The dorsal central nucleus is separated from nucleus dorsomedialis by a cell-free zone (Fig. 4A); caudally, it expands medially and is separated from the dorsal optic nucleus by another cell-free zone (not figured).

Three nonretinal-recipient nuclei (in addition to area triangularis) lie closely apposed to the lateral retinal targets in the rostromedial thalamus. Nucleus dorsomedialis (DM, Figs. $2 \mathrm{~A}, \mathrm{~B} ; 3 \mathrm{~A}, \mathrm{~B} ; 4 \mathrm{~A}$ ) and nucleus dorsolateralis (DL, Figs. 2A, B; 3A) are the most rostral of these cell groups. Nucleus dorsomedialis is a compact group of small, ovoid or round, moderately staining neurons replaced caudally by the pars plicata of nucleus lentiformis thalami (pp, Fig. 4B). Nucleus dorsolateralis contains cells similar to those of nucleus dorsomedialis but are larger and less compact. A prominent nucleus rotundus (R, Figs. 2B; 3A, B; 4A) consists of large, multipolar, moderately staining neurons dispersed amid a dense neuropil. As nucleus rotundus expands to reach its greatest extent at the level of the dorsal optic nucleus, it displaces nucleus dorsomedialis and nucleus dorsolateralis peripherally. Caudally, nucleus rotundus is replaced by the medial posterior nucleus (not figured).

As the thalamic retinal-recipient nuclei drop out, a second group of pretectal retinal nuclei appear adjacent to the optic tract. Labeled fibers pass medially, terminating in nucleus geniculatis pretectalis (GP, Figs. 1, 4B), which includes a plate of moderately staining, large fusiform-shaped cells with a lateral retinalrecipient neuropil. Silver grain densities are especially heavy over two nuclei that lie embedded in optic fibers-nucleus lentiformis mesencephali (LM, Figs. 1, 4B) and the external pretectal nucleus (Pe, Figs. 1, 5A). Nucleus lentiformis mesencephali contains large, deeply staining, multipolar neurons; the cells of the external pretectal nucleus are similar though smaller and more lightly staining. Rostrally, the external pretectal nucleus appears contiguous with nucleus lentiformis 

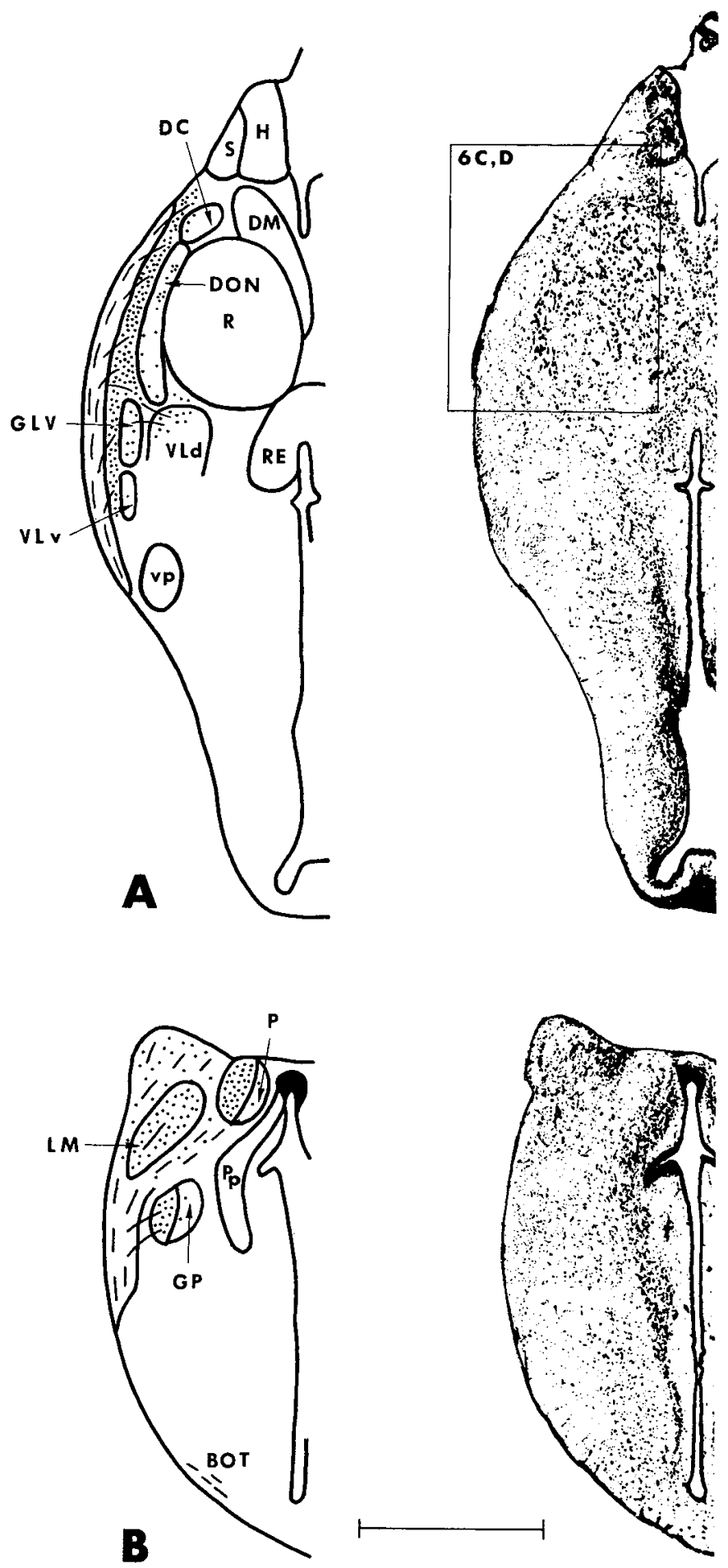

Fig. 4. A) Transverse section through the dorsal optic nucleus at the level of the dorsal central nucleus (DC). B) Transverse section through the rostral pretectum. 

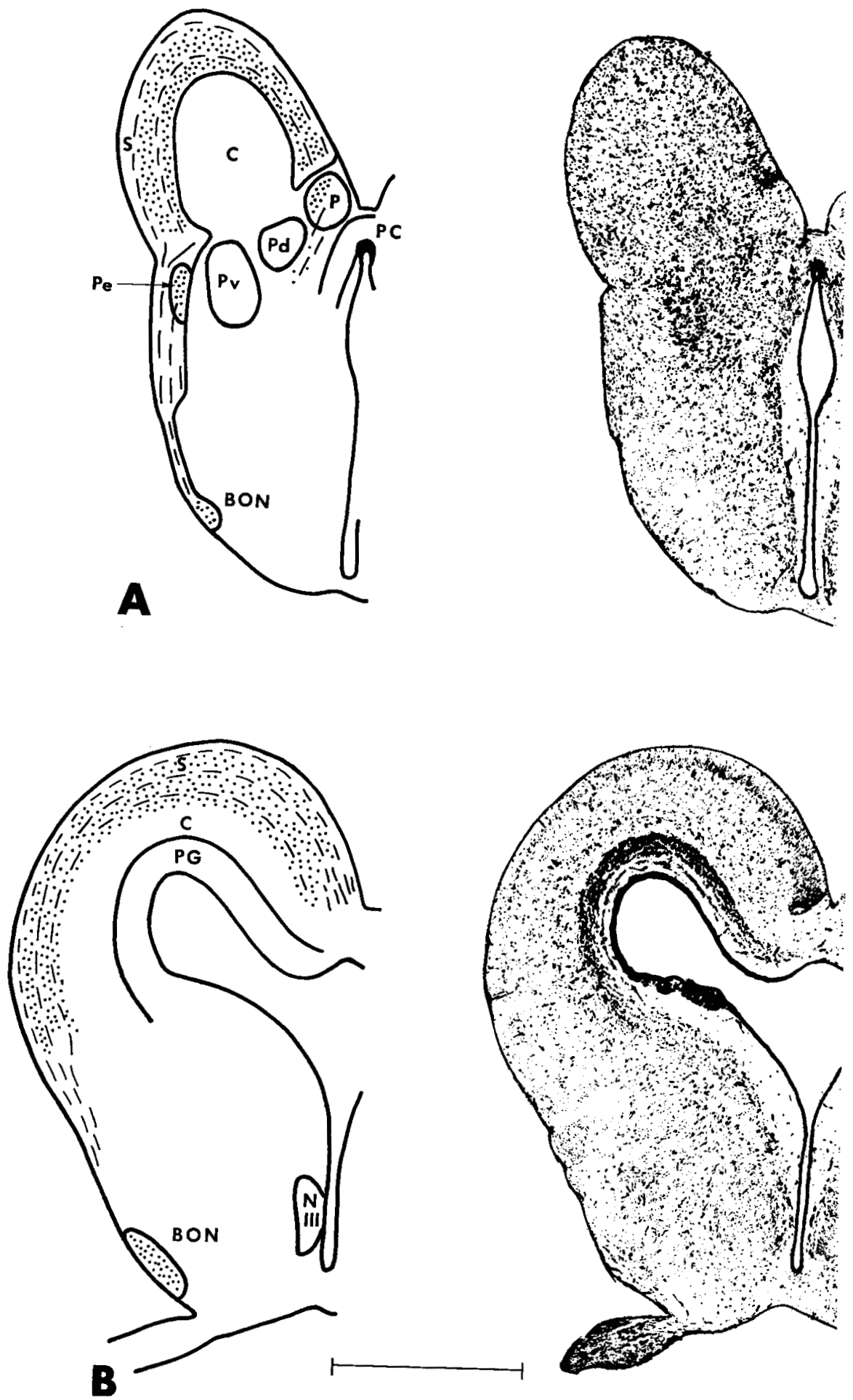

Fig. 5. A) Transverse section through the caudal pretectum at the level of the external pretectal nucleus (Pe). B) Transverse section through the caudal portion of the basal optic nucleus (BON). 

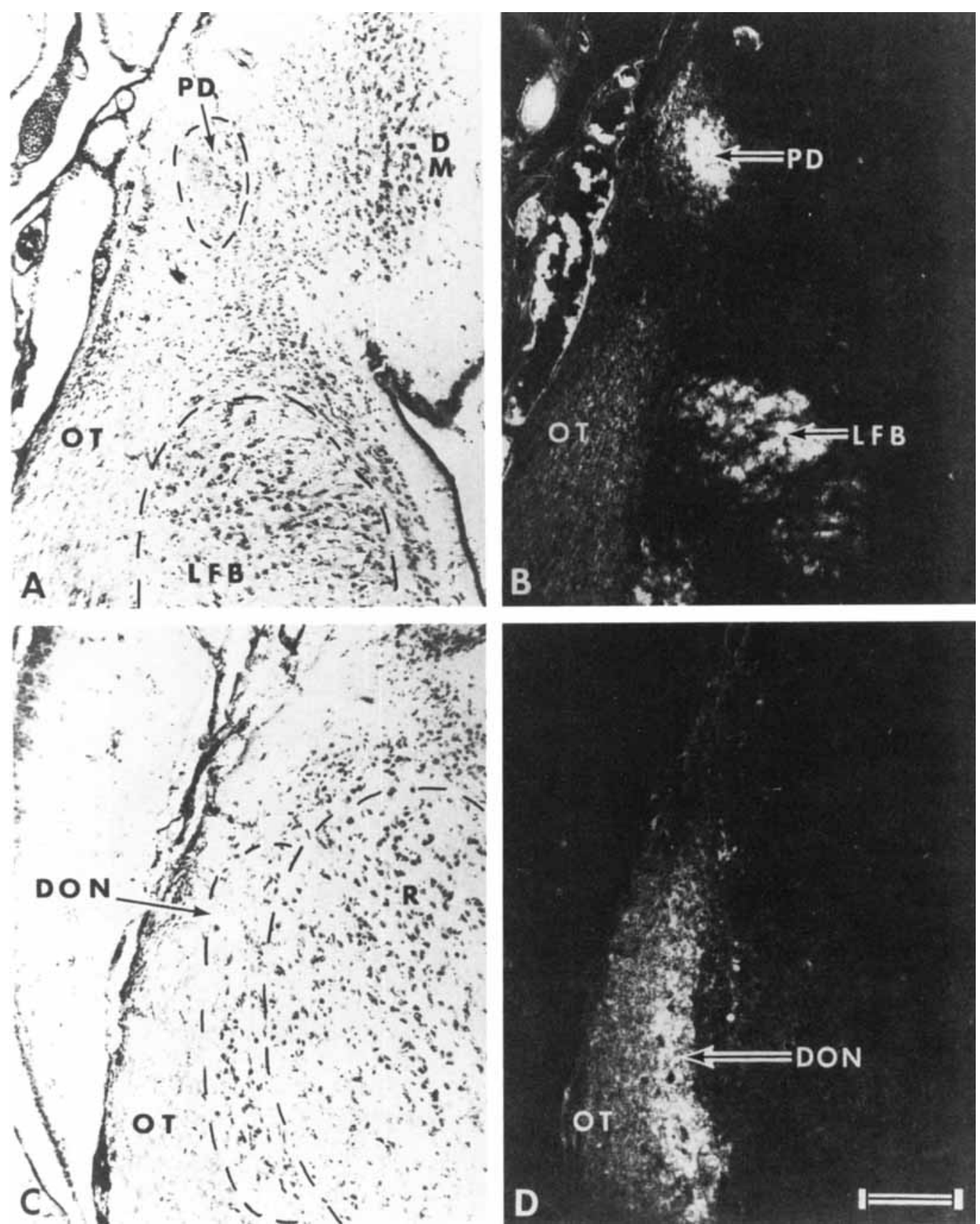

Fig. 6. Photomicrographs of retinofugal pathways revealed by dark-field illumination of autoradiographs appear on the right. Nissl preparations of same sections appear on the left. Bar scale equals $200 \mu$. A, B) Contralateral optic tract (OT) and terminal field in the pars dorsalis of the

lateral geniculate nucleus (PD). Orientation and extent of the photographed field are illustrated in Figure 2A. C, D) Contralateral optic tract and terminal field in the dorsal optic nucleus (DON). Orientation and extent of the photographed field are indicated in Figure 4A. 
mesencephali.

A fourth pretectal retinal target-nucleus posterodorsalis ( $\mathrm{P}$, Figs. $1,4 \mathrm{~B}, 5 \mathrm{~A}$ )-is positioned dorsomedial to nucleus lentiformis mesencephali. Its small, round, lightly staining neurons surround a central circular neuropil that receives the densest retinal input in the pretectum; in autoradiographs the density of silver grains is comparable to that over the neuropil of the pars dorsalis of the lateral geniculate nucleus in the thalamus.

At caudal thalamic levels, retinal fibers separate from the main optic tract to course along the ventrolateral surface of the midbrain tegmentum as a basal (accessory) optic tract (BOT, Fig. 4B), terminating in the basal optic nucleus (BON, Figs. 1; 5A, B). Retinal fibers terminate in a mesh-like fashion amid its darkly staining, large multipolar and small round neurons. Heavy labeling, comparable to that of nucleus posterodorsalis and pars dorsalis of the lateral geniculate nucleus, occurs along the entire rostrocaudal extent of the basal optic nucleus which ends abruptly at the level of the exiting oculomotor nerve.

As retinal efferents terminate in the pretectum, fibers collect to penetrate the superficial zone of the optic tectum. In total, the optic tectum contains three zones, each comprising several laminae (after Ramon, 1896). The superficial retinal-recipient zone consists of laminae 8-14, whereas the deeper nonretinal-recipient central and periventricular gray zones contain, respectively, laminae 6 and 7 and laminae 1-5.

The superficial retinal zone (S, Figs. 5A, B 8A) contains lightly staining, medium and small-sized neurons, widely separated amid a dense neuropil. A laminar organization is evident only after intraocular HRP injections. Fibers in three laminae- 9,12 , and 14-reveal dense clumps of green precipitate (unbuffered dianisidine reaction) or a homogeneous brown product (buffered dianisidine reaction, Fig. $8 C)$. Laminae 12 receives the densest retinal input, and laminae 14 receives the lightest. Intermediate laminae 10,11 , and 13 contain a fine HRP precipitate that we have interpreted as terminal areas (Halpern et al., '76).

In autoradiographs, dense grain deposits appear over laminae 9-14 (Fig. 8B). Grain density over deeper tectal layers is above background levels, but is markedly less than the density over the superficial zone, as reported for other ectotherms (Cruce and Cruce, '75; Landreth et al., '75). Presumably, the increased grain density in the deeper region is due to diffusion and/or active transport of radioactive molecules. Recent evidence suggests that labeled proline released during transport along retinal axons may be reutilized in tectal protein synthesis (Heacock and Agranoff, '77).

The optic tectum did not label uniformly in all cases; either the medial or the lateral half revealed a heavier concentration of silver grains. Differential labeling of the superficial zone was also seen in the HRP cases, where the reaction product was often nonhomogeneous along the mediolateral axis of the tectal roof. With neither method was there an apparent relationship between label distribution and the survival time or the differential labeling of other retinal targets; the retinal ganglion cell layer was not checked for differential labeling.

The HRP material confirmed all contralateral retinal targets revealed by autoradiography, but did not indicate the ipsilateral fibers or terminals seen in autoradiographs.

The nonretinal-recipient central zone $(\mathrm{C}$, Figs. 5A, B; 8A) contains a broad zone of moderately staining, round or ovoid-shaped neurons-lamina 7-and a fibrous layer formed by the descending tectobulbar tracts and the tectal commissure-lamina 6 . The periventricular gray zone (PG, Figs. 5A, B; 8A) contains two layers of darkly staining round or ovoid-shaped neurons-laminae 3 and 5-and a compact ependymal layer of deeply staining columnarlike cells-lamina 1 . Lamina 5 is a compact stratified zone, whereas lamina 3 is a single cell layer. Laminae 2 and 4 are fibrous layers.

Ipsilateral projections. A small fascicle of optic fibers issues from the dorsal aspect of the optic chiasm and courses along the medial aspect of the ipsilateral optic tract. This pathway is sparsely labeled, but grain densities are markedly above background levels over the following ipsilateral areas: pars dorsalis of the lateral geniculate nucleus (Fig. 7A); pars ventralis of the lateral geniculate nucleus; the dorsal optic nucleus (Fig. 7B); the basal optic nucleus; and laminae 9 and 12 of the optic tectum (Fig. 8B). Optimal labeling of these targets occurred by 48 and 72 hours. Compared to contralateral grain densities (Fig. 6). ipsilateral grain densities are sparser (Figs. 7, 8B), but ipsilateral terminal zones are uniformly labeled and their topography overlaps that of the contralateral terminal fields. The ipsilateral projection to the optic tectum is confined to parts of the medial and lateral walls of the superficial zone, and these areas converge at the caudal wall of the tectum to form a peripheral band within the superficial tectal zone. 
A

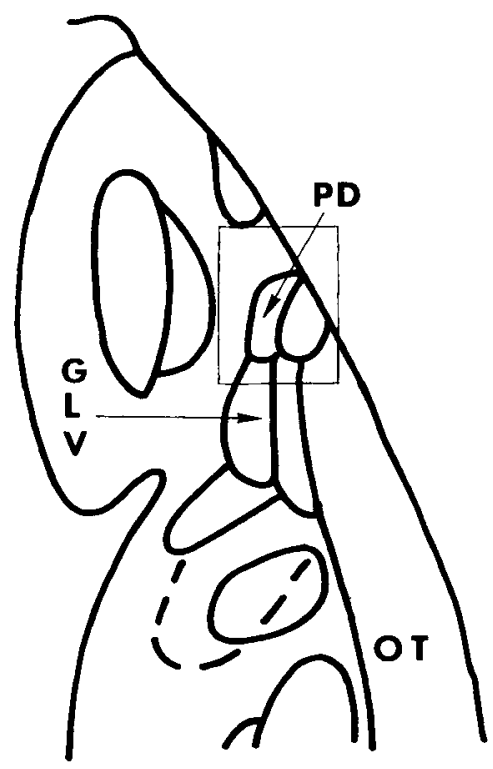

B

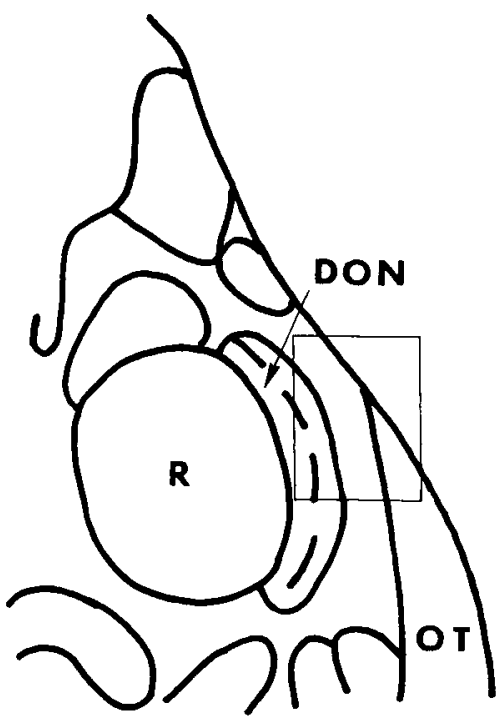

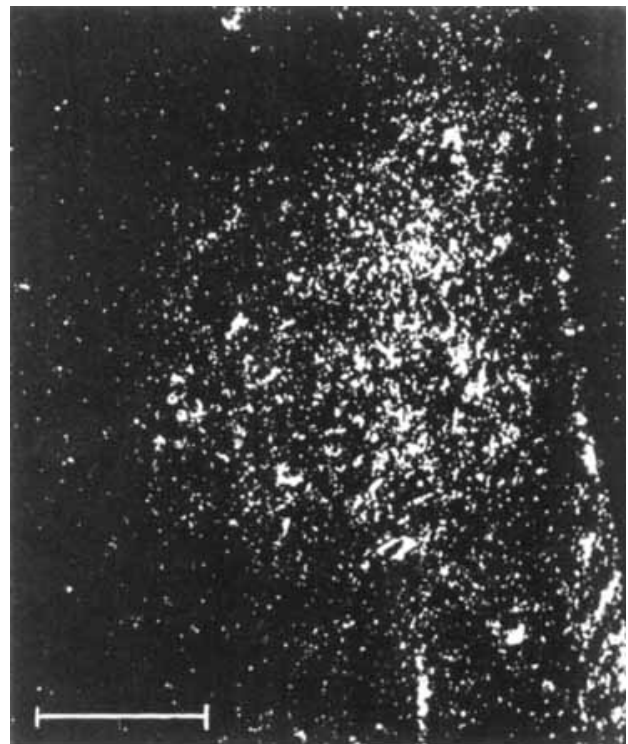

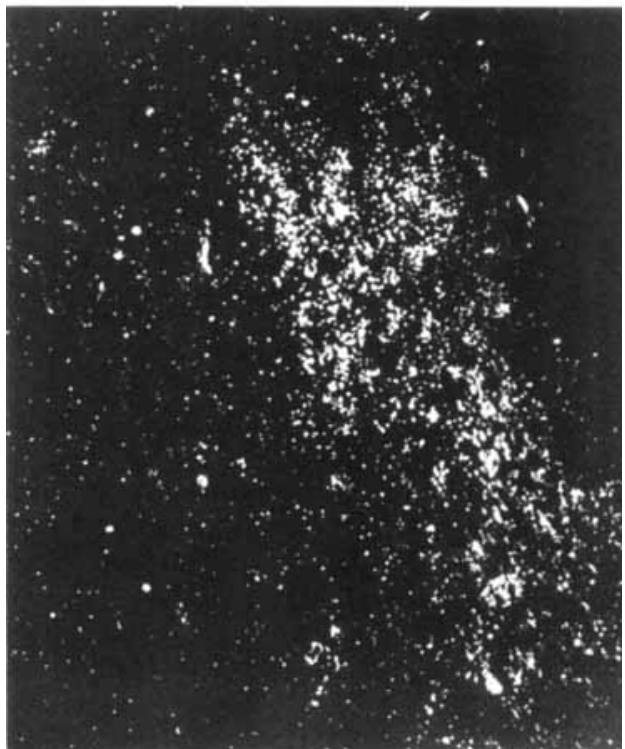

Fig. 7. Photomicrographs of retinofugal projections revealed by dark-field illumination of autoradiographs appear on the right. Line drawings on the left illustrate orientation and extent of the photographed fields adapted from Figure 2A (A) and Figure 3B (B). A) Ipsilateral optic tract and terminal field in the pars dorsalis of the lateral geniculate nucleus. B) Ipsilateral optic tract and terminal field in the dorsal optic nucleus. Stained optic tract fibers appear white though they are very sparsely labeled (see text). Bar scale equals $100 \mu$. 

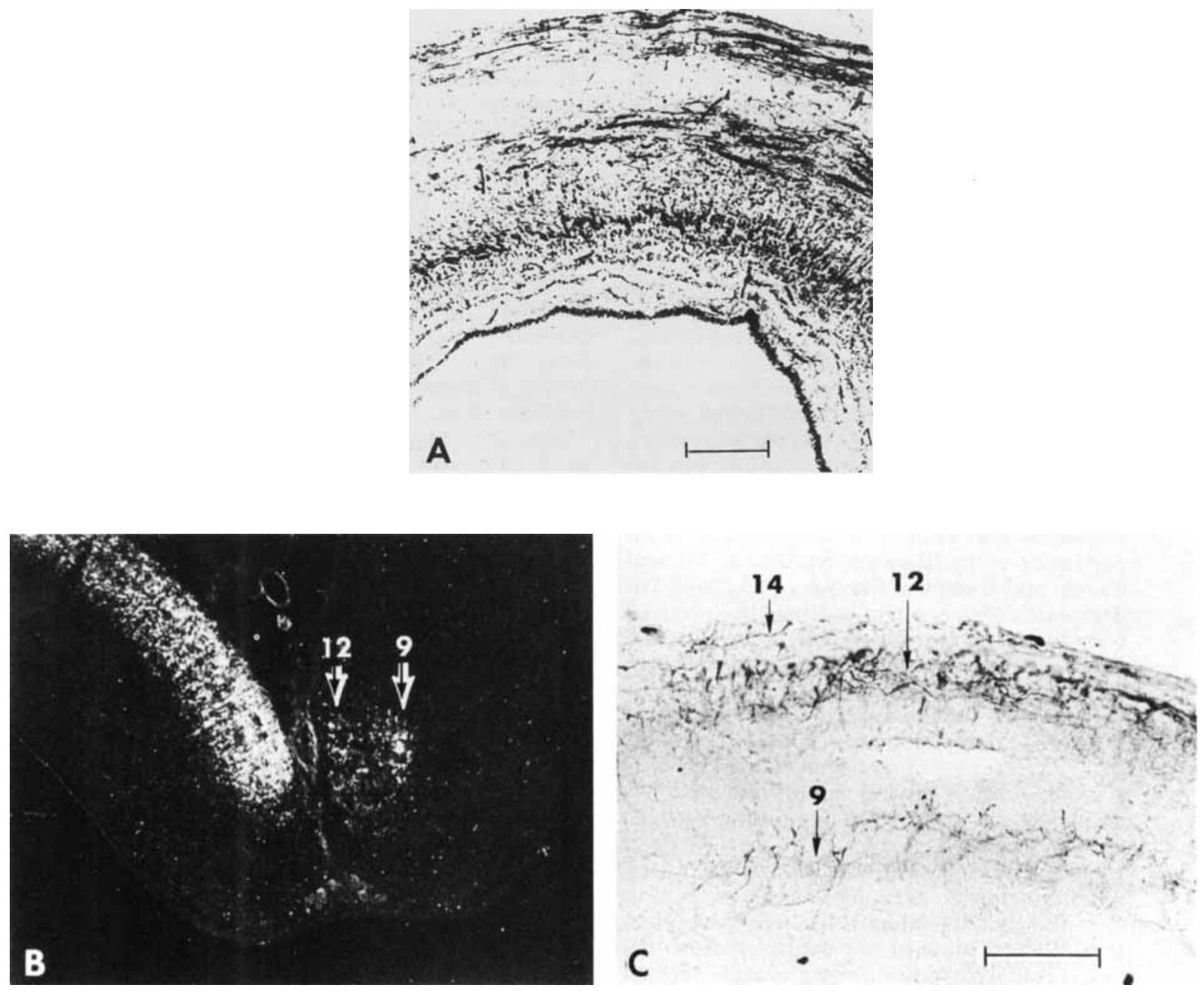

Fig. 8. Photomicrographs of the optic tectum. A) Sagittal section of Kluver-Barrera preparation depicting superficial (S), central (C) and periventricular gray (PG) zones. The bar scale for A and B equals $200 \mu$. B) Dark-field photomicrograph of an autoradiograph in the transverse plane. The contralateral terminal field is to the left; the superficial zone is labeled throughout laminae 14-9. The ipsilateral terminal field is to the right; the labeled medial superficial zone is restricted to laminae 12 and 9. C) Photomicrograph of a transverse section through the superficial zone of an animal that received an intraocular HRP injection. Contralateral fibers are labeled within laminae 14, 12, and 9. Bar scale equals $100 \mu$.

\section{DISCUSSION}

\section{Comparisons with earlier studies}

Autoradiographic analysis of the retinofugal pathways in the turtle Chrysemys picta reveals 12 retinal targets in the diencephalon and the mesencephalon. These targets are most similar in number and topography to that reported for Podocnemis (Knapp and Kang, '68b), allowing for nomenclature differences (see Table 1).
Five and six thalamic targets have been previously identified in Podocnemis (Knapp and Kang, '68b) and Chrysemys (Bass, '76), respectively. Five thalamic targets are also illustrated for Emys (Kosareva, '67), whereas four are described for Chelydra (Knapp and Kang, '68a). Although Knapp and Kang ('68a) did not recognize a retinal input zone comparable to the dorsal optic nucleus of Chrysemys or the dorsal lateral geniculate nucleus of Podoc- 
nemis (see Table 1), additional autoradiographic data for Chelydra (unpublished observations) confirm its presence.

In contrast to the above studies, only two thalamic retinal targets are described for Pseudemys (Hall and Ebner, '70a). While these discrepancies could be due to species differences, it is noteworthy that our study presents experimental data in the context of a cytoarchitectural analysis of retinal-recipient zones, as did Knapp and Kang's ('68a, b). Kosareva adhered to Papez's ('35) descriptive analysis of the thalamus of Chelonia. Hall and Ebner utilized Papez's nomenclature without explaining their divergence from the number of subdivisions recognized in the lateral thalamus by Papez or other authors (see Table 1). Parceling of the lateral thalamus into two nuclei appears to us unfounded on the basis of cellular aggregations, staining properties, and retinal terminal fields. Our studies of Chrysemys (this report) and Caretta (Bass and Northcutt,'75), and Knapp and Kang's of Chelydra ('68a) and Podocnemis ('68b) confirm at least three retinal targets ventral to a dorsal optic zone. Hall and Ebner ('70a) include the densest retinal target-our pars dorsalis (Table 1) - as part of a ventral geniculate complex, but later identified it as area triangularis (Fig. 2, sec. 81; Hall et al., '77). The pars dorsalis, as defined here, is separate from a rostral nonretinal area triangularis, as well as the remaining retinalrecipient nuclei.

Similarly, Hall and Ebner ('70a) illustrated a retinal-recipient area pretectalis extending from the caudal thalamus through the pretectum. Within this zone, we identify distinct terminal zones adjacent to a dorsal central nucleus at caudal thalamic levels and a nucleus posterodorsalis at pretectal levels. The latter corresponds to Papez's area pretectalis (Table $1)$.

\section{Ipsilateral retinal pathways}

Several lines of evidence argue that the ipsilateral labeling is not the result of transneuronal transport. This phenomenon has not been reported with less than 11 days' survival time in ectotherms (Landreth et al., '75; Lázár, '76), whereas ipsilateral terminal fields were seen in Chrysemys after 48 and 72 hours. In addition, similar ipsilateral retinal projections have been reported in other ectotherms after short survival times (Cruce and Cruce, '75; Repérant and Rio, '76; Springer and Landreth, '77; Repérant et al., '78). Finally, if transneuronal transport were occurring with short survival times, the label should be particularly obvious in tectal-recipient nuclei, such as nucleus rotundus or nucleus isthmi (Foster and Hall, '75). However, grain counts above background are not seen in these regions before 5 days' survival time. Even then, grain densities are observed only in the ipsilateral tectal-recipient nuclei and thus do not indicate confounding of the ipsilateral retinal projections.

An ipsilateral retinal pathway, as observed in Chrysemys was reported in Emys (Kosareva, '67) but the ipsilateral terminal fields were not described. Ipsilateral retinothalamic and -pretectal pathways as recognized in Chrysemys are commonly reported for lizards and snakes (reviews: Northcutt and Butler, '74a; Repérant et al., '78).

Reports of the presence of ipsilateral retinotectal pathways are more variable. In Chrysemys, the ipsilateral projection is restricted to laminae 9 and 12 and in Tupinambis (Cruce and Cruce, '75) to laminae 9, whereas in Vipera (Repérant and Rio, '76) and Gekko (Northcutt and Butler, '74a) it extends to several laminae. Ipsilateral retinotectals are unreported for several lizards (Repérant et al., '78), crocodilians (Braford, '73), and the tuatara, Sphenodon (Northcutt et al., '74). Thus the presence and topography of ipsilateral retinal pathways are extremely varied among reptiles, and their functional and phylogenetic significance is unclear (see Northcutt and Butler, '74a; Repérant et al., '78).

\section{Phylogenetic considerations}

The retinal targets described for Chrysemys are similar to those reported in other reptiles (reviews: Northcutt and Butler, '74a, b; Repérant et al., '78; Butler and Northcutt, '78). The number and topography of thalamic targets in particular compares closely to those of two lizards, Gekko and Iguana (Butler and Northcutt, '78). In those turtles and lizards examined, three retinal targets occur ventral, and two dorsal, to a nucleus geniculatis pars dorsalis. In lizards, an additional target-nucleus intercalatus thalami-appears medial to a pars dorsalis. Two points should be emphasized: 1) Our pars dorsalis of Chrysemys corresponds topographically to the same-named nucleus in lizards. 2) The pars dorsalis is not the most dorsal thalamic retinal target in either turtles or lizards. A second nucleus - the dorsal optic nucleus-lies immediately dorsal to the pars dorsalis and is the most expansive group in the lateral thalamus of turtles, whereas a more 
ventral group-the ventral geniculatedominates the lateral thalamus of lizards.

Recent HRP data have documented reciprocal connections of our dorsal optic nucleus with the dorsal pallium in Pseudemys and Chrysemys (Hall et al., '77). On this basis, the retinothalamo-telencephalic pathway in turtles has been compared to the retinogeniculostriate pathway in mammals (Hall et al., '77; see also Hall and Ebner, '70b; Hall, '72). This comparison is based on the recognition of only two thalamic retinal targets-dorsal and ventral lateral geniculate nuclei. While the dorsal optic nucleus may represent a homologue of the pars dorsalis of the lateral geniculate nucleus, the retinal autoradiographs for Chrysemys suggest a more complex pattern of thalamotelencephalic relationships than previously suspected for turtles. The lateral thalamus of turtles comprises six retinal-recipient nuclei. The dorsal optic nucleus or other cell groups may project to additional nuclei other than dorsal cortex. Recent data for mammals depict extrageniculate retinal input (Berman and Jones, '77), to the striate cortex (Cooper et al., '79) and geniculate input to extrastriate cortex (Höllander and Vanegas, '77), emphasizing the complexities of thalamo-telencephalic pathways among extant vertebrates. Indeed, further experimental data on the pattern of thalamic efferents among reptiles are needed before the phylogenetic history of the dorsal geniculate nucleus of mammals can be understood.

\section{ACKNOWLEDGMENTS}

The authors are pleased to thank Dr. Mark R. Braford Jr. for his collaboration with the HRP experiments, Ms. Margaret Ann Marchaterre for assistance with the illustrations, and Ms. Mary Sue Caudle Northcutt for editing the final manuscript and providing many helpful suggestions. This study was supported by NIH grants to R.G.N. and an NIH postdoctoral fellowship to A.H.B.

\section{LITERATURE CITED}

Bass, A.H. (1976) Retinal projections in the painted turtle, Chrysemys picta. Neurosci. Abstr. 2:177 (Abstract).

Berman, N., and E.G. Jones (1977) A retino-pulvinar projection in the cat. Brain Res. 134:237-248.

Braford, M.R., Jr. (1973) Retinal projections in Caiman crocodilus. Am. Zool. 13:1345.

Butler, A.B., and R.G. Northcutt (1971) Retinal projections in Iguana iguana and Anolis carolinensis. Brain Res. 26:1-13.

Butler, A.B., and R.G. Northcutt (1973) Architectonic studies of the diencephalon of Iguana iguana (Linnaeus). J. Comp. Neurol. 149:439-462.

Butler, A.B., and R.G. Northcutt (1978) New thalamic visual nuclei in lizards. Brain Res. 149:469-476.

Colman, D.R., F. Scalia, and E. Cabrales (1976) Light and electron microscopic observations on the anterograde transport of horseradish peroxidase in the optic pathway in the mouse and rat. Brain Res. 102:156-163

Cooper, H.M., H. Kennedy, M. Magnin, and F. Vital-Durand (1979) Thalamic projections in a prosimian primate, $\mathrm{Mi}$ crocebus murinus. J. Comp. Neurol. 187:145-168.

Cruce, J.A.F. (1974) A cytoarchitectonic study of the diencephalon of the Tegu lizard, Tupinambis nigropunctatus. J. Comp. Neurol. 153:215-238.

Cruce, W.L. R., and J.A.F. Cruce (1975) Projections from the retina to the lateral geniculate nucleus and mesencephalic tectum in a reptile (Tupinambis nigropunctatus): A comparison of anterograde transport and anterograde degeneration. Brain Res. 85:221-228.

Cruce, J.A.F., and W.L.R. Cruce (1978) Analysis of the visual system in a lizard, Tupinambis nigropunctatus. In N. Greenberg and P.D. MacLean (eds.): Behavior and Neurology of Lizards. NIMH.

Foster, R.E., and W.C. Hall (1975) The connections and laminar organization of the optic tectum in a reptile (Iguana iguana). J. Comp. Neurol. 163:397-426.

Hall, J.A., R.E. Foster, F.F. Ebner, and W.C. Hall (1977) Visual cortex in a reptile, the turtle (Pseudemys scripta and Chrysemys picta). Brain Res. 130:197-216.

Hall, W.C. (1972) Visual pathways to the telencephaion in reptiles and mammals. Brain Behav. Evol. 5:95-113.

Hall, W.C., and F.F. Ebner (1970a) Parallels in the visual afferent projections of the thalamus in the hedgehog (Paraechinus hypomelas) and the turtle (Pseudemys scripta). Brain Behav. Evol. 3:135-154.

Hall, W.C., and F.F. Ebner (1970b) Thalamotelencephalic projections in the turtle (Pseudemys scripta). J. Comp. Neurol. 140:101-122.

Halpern, M., R.T. Wang, and D.R. Colman (1976) Centrifugal fibers to the eye in a nonavian vertebrate: Source revealed by horseradish peroxidase studies. Science 194:1185-1188.

Heacock, A.M., and B.W. Agranoff (1977) Reutilization of precursor following axonal transport of $\left({ }^{3} \mathrm{H}\right)$ prolinelabeled protein. Brain Res. 122:243-254.

Höllander, H., and H. Vanegas (1977) The projection from the lateral geniculate nucleus onto the visual cortex in the cat. A quantitative study with horseradish peroxidase. J. Comp. Neurol. 173:519-536.

Huber, G.C., and E.C. Crosby (1926) On thalamic and tectal nuclei and fiber paths in the brain of the American alligator. J. Comp. Neurol. 40:98-224.

Huber, G.C., and E.C. Crosby (1933) The reptilian optic tectum. J. Comp. Neurol. 57:57-163.

Huber, G.C., and E.C. Crosby (1943) A comparison of the mammalian and reptilian tecta. J. Comp. Neurol. 78:133-168.

Knapp, H., and D.S. Kang (1968a) The visual pathways of the snapping turtle (Chelydra serpentina). Brain Behav. Evol. 1:19-42.

Knapp, H., and D.S. Kang (1968b) The retinal projections of the side-necked turtle (Podocnemis unifilis) with some notes on the possible origin of the pars dorsalis of the lateral geniculate body. Brain Behav. Evol. 1:369-404.

Kosareva, A.A. (1967) Projection of optic fibers to visual centers in a turtle (Emys orbicularis). J. Comp. Neurol. 130:263-276.

Kuhlenbeck, H. (1931) Über die Grundbestandteile des Zwischenhirnbauplans bei Reptilien. Morph. Jhb. $66: 244-317$

Landreth, G.E., E.A. Neale, J.H. Neale, R.S. Duff, M.R. Braford Jr., R.G. Northcutt, and B.W. Agronoff (1975) Evaluation of $\left({ }^{3} \mathbf{H}\right)$ proline for radioautographic tracing of axonal projections in the teleost visual system. Brain Res. 
$91: 25-42$.

Lázár, G. (1976) Transneuronal transport in the frog visual system. Brain Res. 109:623-627.

Northcutt, R.G. (1977) Retinofugal projections in the lepidosirenid lungfishes. J. Comp. Neurol. 174:553-574.

Northcutt, R.G., M.R. Braford Jr., and G.E. Landreth (1974) Retinal projections in the tuatara Sphenodon punctatus: An autoradiographic study. Anat. Rec. 178:428 (Abstract).

Northcutt, R.G., and A.B. Butler (1974a) Evolution of reptilian visual systems: Retinal projections in a nocturnal lizard, Gekko gecko (Linnaeus). J. Comp. Neurol. 157:453-466.

Northcutt, R.G., and A.B. Butler (1974b) Retinal projections in the northern water snake Natrix sipedon sipedon (L.).J. Morphol. 142:117-136.

Papez, J.W. (1935) Thalamus of turtles and thalamic evolution. J. Comp. Neurol. 61:433-475.

Repérant, J. (1973) Les voies et les centres optiques pri- maires chez la vipère (Vipera aspis). Arch. Anat. Micr. Morph. Exp. 62:323-352.

Repérant, J. (1975) Nouvelles données sur les projections retiniennes chez Caiman sclerops. Etude radio-autographique. C.R. Acad. Sc. (Paris). 280:2881-2884.

Repérant, J., and J. Rio (1976) Retinal projections in Vipera aspis. A reinvestigation using light radioautographic and electron microscopic degeneration techniques. Brain Res. 107:603-609.

Repérant, J., J.P. Rio, D. Micelli, and M. Lemire (1978) A radioautographic study of retinal projections in Type $I$ and Type II lizards. Brain Res. 142:401-411.

Senn, D. (1968) Bau und Ontogenese von Zwischen und Mittelhirn bei Lacerta sicula (Raffinesque). Acta Anat. (Suppl) 55:1-150.

Springer, A.D., and G.E. Landreth (1977) Direct ipsilateral retinal projections in goldfish (Carassius auratus). Brain Res. 124:553-537. 